Levytskyi Victor,

Candidate of Philosophical Sciences,

Director of Ukrainian Institute for Global Development and Adaptation Strategies, Kyiv

\title{
WHAT IS MODERN: DISCOURSE ON MODERNIZATION AS WAY OF SELF-COMPREHENSION OF MODERN
}

In the article an attempt of inteprepretation the discourse about modernization as a way of self-understanding the Modern is being made. Importance of this way, which at the time of postmodernist denial of universal ways of cognition appears as one of a few legitimate variants of rational comprehension of the Modern, is being marked. However, the analysis of several authoritative concepts in this sphere allows to come to a conclusion that Modern is a local cultural formation, expansionist ideology of which doesn't turn non-Modern states into new regions of Modern, but directs their development to the path of satellites of Modern.

Keywords: Modern; modernization; modernity; discours; rationality.

\section{REFERENCES}

1. Alexander J. C. (2013), The Meanings of Social Life: A Cultural Sociology, Praxis, Moscow, 640 p. (rus).

2. Bilokobylskyi O. (2008), The foundations and strategies of the Modern rationality, Parapan, Kyiv, 244 p. (rus).

3. Bechmann G. (2014), Modern society: risk society, information society, knowledge society, Logos, Moscow, 248 p. (rus).

4. Festherstone M., Lash S., Robertson R. (2008), Global Modernities, Nika-Tsentr, Kyiv, 400 p. (ukr).

5. Efremenko D. (2006), Eco-Political discourses. The emergence and evolution, ISISS RAS, 284 p. (rus).

6. Latour B. (2006), We Have Never Been Modern, European University Press, S-Petersberg, 240 p. (rus).

7. Lukach J. (2003), The End of the Twentieth Century and the End of the Modern Age, Science, S-Petersberg, 256 p. (rus).

8. Fedotova V. (2010), Changing sociality: new forms of modernization and progress, IPHRAS, Moscow, 274 p. (rus).

9. Muravykh A. (1984), Materialization of the noospheric-ecological idea, Safety, 1984, № 3, p. 87 (rus). (rus).

10. Fedotova V. (2013), Socio-philosophical analysis of modernization: theories, models, experience, IPHRAS, Moscow, 221 p.

11. Hösle V. (1994), Philosophy and Ecology, Kami, Moscow, 192 p. (rus).

12. Global Trends 2025. A Transformed World. National Intelligence Council Report (2008), US Government Printing Office, Washington, 99 p. (eng).

(C) Левицький Віктор

Надійшла до редакції 18.05.2015

УДК 21.284

ЛЕВЧЕНКО ТЕТЯНА, старший викладач кафедри політології та філософіі

Наџіонального університету державної податкової служби Украйни, м. Ірпінь

\section{ІНТЕРПРЕТАЦІЇ КОНЦЕПТУ ВІРИ В СУЧАСНІЙ ПРОТЕСТАНТСЬКІЙ ТЕОЛОГІї}

\begin{abstract}
У статті простежено основні закономірні інтерпретації феномену віри в сучасній протестантській теології. Автор доходить висновку, що сучасна протестантська теологія розуміє віру неметафізично й персоналістично. Так, К. Барт під вірою розуміє новий спосіб життя особистості, той справжній спосіб існування, який екзистенціалісти відрізняли від існування звичайного. Цей спосіб життя можливий після прийняття особистістю власного засудження, усвідомленого внаслідок проповіді християнської керігми (звістки). Протестантська теологія кінця XX - початку XXI століття розуміє віру як вірність спільноти Богові та визнання біблійного наративу (Н. Т. Райт). Альтернативною концепцією є розуміння віри як інтуїтивного знання (Дж. Мілбанк).
\end{abstract}

Ключові слова: сучасна теологія; віра; керігма; наратив.

Постановка проблеми і стан її вивчення. Актуальність нашого дослідження пов'язана з необхідністю осмислення процесів парадигмальних змін у розумінні віри в сучасній протестантській теології. Визначення того, чим $є$ віра у XX столітті, перестало бути правом церковної влади. Нові інтерпретації концепту віри 
створюються протестантськими теологами в діалозі або ж у протистоянні із сучасним секулярним світоглядом, науковим, фрілософським, суспільним. Різноманіття інтерпретацій концепту віри, пов'язане зі свободою теологічної творчості, не є безмежним, і можна виділити дві основні тенденції: екзистенціалістичну парадигму розуміння віри в період від закінчення Першої світової війни до падіння Берлінського муру та наративну парадигму, що виникла наприкінці XX століття й активно розвивається сьогодні. Сучасні дискусії в протестантській теології щодо віри потребують релігієзнавчого аналізу, який дозволив би чітко усвідомити й описати особливості парадигмальних концептів віри в цій теології.

Наше дослідження ґрунтується на теорії парадигмального аналізу теологічних знань, запропонованій Г. Кюнгом [1] та Г. У. фон Бальтазаром [2], розвинутій сучасними дослідниками Т. Роуленд [3; 4], Ф. Керром [5], А. Колодним [6], Ю. Чорноморцем [7], Г. Христокіним [8]. Поняття панівного й альтерантивного наративу використовується нами в тому значенні, яке воно здобуло в Е. Брюггемана: панівний наратив $€$ основоположною для спільноти розповіддю зі своїми концептами, цінностями, драматикою боротьби добра і зла, виправданням наявного стану речей; альтеративний наратив пропонує нові інтерпретації концептів та цінностей, нову розповідь про драму боротьби сил світу й темряви, пропонує зміни наявного стану речей в парадигмі "звільнення".

Мета нашого дослідження - виявлення основних закономірних інтерпретацій феномену віри в сучасній протестантській теології.

Виклад основного матеріалу. Як було доведено в наших попередніх публікаціях, модерна парадигма сприйняття віри передбачала її зведення до інтуїції містичної (Ф. Шлейєрмахер, Р. Отто, православна теологія) чи моральної (кантіанство й ліберальна теологія) [9]. Католицька теологія XIX - початку XXI століть розвивала метафрізичну концепцію віри як згоди розсудку із тезами догматичної теології. При цьому вся наукова й філософська раціональність редукувалась до розсудкової метафізики, а щодо віри заперечувалась можливість її інтуїтивних чи персоналістичних тлумачень. Із середини XX століття цим метафрізичним положенням про раціональність та віру надавалася екзистенційна інтерпретація, особливо яскраво розвинута папою Іваном Павлом II в енцикліці "Fides et ratio". Постметафрізичною католицька концепція віри стає лише в межах діалогічної парадигми розуміння віри. Таким чином, не пройшовши модернізації, домодерне метафізичне вчення католицизму про віру відразу потрапляє в горнило постметафізичного розуміння віри.

Протестантська теологія на початку XX століття в цілому мала інше, неметафізичне розуміння віри. А саме: для протестантських теологів початку XX століття віра була переважно моральною інтуїцією, внутрішньо спорідненою із совістю. Предметом дискусій було лише питання про те, чи є ця віра набутою, чи вона апріорно властива людині, а під дією благодаті лише актуалізується $[10$, с. $36-41]$.

Видатний протестантський теолог К. Барт у своїй знаменитій праці "Послання до Римлян" радикально повертається до того розуміння віри, яке було у творах отців Реформації і яке було практично забуте в протестантській традиції, за винятком хіба що С. К'єркегора. За К. Бартом, віра є надприродним актом, який здійснюється "по той бік" від усіх людських здібностей, апріорних і набутих, "по той бік" усякого природного людського досвіду - "релігійного" й "цілісного". Віра не належить людині, не породжується нею. Але водночас віра - це не лише плід дії Бога, при якій людина - лише пасивний інструмент. Віра також і не синергія дії благодаті та дії людини. За К. Бартом, віра виникає в ситуації діалогу, є відповіддю людини на керігму, яка повідомляється церквою чи прямо Писанням. Людина відповідає як історична екзистенція на керігму, яку К. Барт розуміє неісторично, як таку, що походить зі священної історії, яка стала вічною. Відповідь на керігму вірою $є$ плодом дії Духа Святого, є чудесним актом і надприродною подією.

Віра ні на що не спирається, не має аніякого ґрунту, але, навпаки, сама стає основою для християнського мислення й життя. Віра є ризиком, який особистість приймає як ризик жити без-основно. "Віра ніколи не готова, ніколи не дана, ніколи не гарантована, з точки зору психології вона є новим стрибком у невідомість, у темноту, у вакуум" [11, с. 70]. Вірі не передують жодні аргументи щодо вірогідності того, у що потрібно вірити, чи оцінні судження щодо гідності Того, у Кого потрібно вірити. "Не існує людських умов (наприклад, педагогічних, інтелектуальних, економічних, психологічних), які повинні бути виконані перед прийняттям віри. Не існує ніякого людського руху, ніякого рятівного шляху, жодної градації на шляху до віри, яку потрібно було попередньо пройти. Віра завжди первинна, вона - передумова й основа" [Там само, с. 71]. У цьому відношенні віра, за К. Бартом, цілком ірраціональна. Вона не має людської достовірності, і К. Барт різко наголошує: "Віра не $є$ само собою зрозуміле й ніколи такою не буде" [Там само, с. 70]. Він виступає за викорінення не лише раціональних, але й будь-яких людських елементів із віри: "Ми вимагаємо віри. Ми не вимагаємо віри в нашу віру, оскільки ми знаємо: те у нашій вірі, що від нас, не достовірне" [Там само, с. 71]. Віра $є$ властивістю Бога, і людині належить лише внаслідок того, що людина може їі собі засвоїти. "Віра - це сама вірність Божа" [Там само, c. 70], і ця вірність Бога як істина не є загальнодоступною, бо інакше "вона не була б праведністю Божою для світу і спасінням для всіх" [Там само]. Людина приймає віру як новий спосіб світоглядної орієнтації, ще не до кінця розуміючи, що приймає цілий спосіб життя: "Віра - це навернення, радикально нова переорієнтація людини, яка оголюється перед Богом, стає бідною заради придбання дорогоцінної перлини, яка губить свою душу ради Ісуса" [Там само].

Віра $€$ екзистенціалом, і навіть більше - способом існування, самою екзистенцією для віруючого. Існування до віри К. Бартом оцінюється як несправжнє, а існування у вірі - як справжнє. Протистояння справжнього і несправжнього існувань $€$ базовим для екзистенціалізму, і його ми бачимо в теології К. Барта як не менш важливе, ніж у філософії М. Гайдеґґера. Несправжня людина має "померти", справжня людина, тобто "людина віри", має народитися. Нова людина не має використовувати нічого із людини старої, яка має померти чи помирає - ні розуму, ні відчуттів, ні емоцій, ні досвіду. У нової людини усе нове: і розум, і відчуття, й емоції, і досвід.

Розум і відчуття віри, емоції та досвід віри є протилежними не лише до своїх світських попередників, але й до звичайних релігійних аналогів. К. Барт особливо гостро протестує проти намагання мислити "релігійний досвід" як певну сполучну ланку між людиною та Богом. За К. Бартом, "релігійний досвід" - це людські фантазії, емоції, думки, що є "хмарою туману" між людиною і Богом. Живучи "релігійним досвідом", людина уявляє, що піднімається до Бога, торкається Його, спілкується 3 Ним, але насправді вона залишається сама по собі. Реалістичне визнання власної неспроможності знати 
Бога $є$ кращим, ніж фантазії про богоспілкування через релігійний досвід.

Достовірність віри як надприродного екзистенціалу та способу існування для К. Барта пов'язана винятково з тим, що ця віра переживається як надприродне життя, яке розвивається в особистості після містичної смерті [Там само, с. 97-98]. Визнання власного безсилля спасатися, визнання власної засудженості тлумачиться ним як визнання вироку над природньою люди ною, яка невідворотно грішна й винна [Там само, с. 97]. Бог заперечує людину, її заслуги, її "досвід", але людина говорить "так" у відповідь на вирок Бога щодо грішників і лише просить про милосердя [Там само, с. 97-98]. Це "так" $є$ радикальною згодою жити з Богом, відмовившись від свого звичного способу життя. Також і в Божому запереченні звичайного людського існування $€$ пропозиція більшого й кращого життя, надприродного існування. Це означає, що надприродне життя не надбудовується над природнім як другий поверх будинку над першим чи стіни над фундаментом, як то маємо в томізмі та інших різновидах католицизму. Віра не $є$ завершенням устремлінь людського розуму, волі, емоцій. К. Барт уважає ці відносини з Богом, у яких народжується віра, такими, що не можуть бути предметом людських фантазій, проекцій, домислів. Саме тому віра як спосіб життя "людини віри" після "смерті" "звичайної людини" має найвищу внутрішню достовірність. К. Барт пише: "Це відношення не має стати об'єктом нового обману й нових ілюзій. У своєму критичному вивищенні воно цілком захищене від олюднення. Адже життя, яке творить це відношення, - це життя через смерть, знову і знову через смерть" [Там само, с. 98]. Очевидно, що достовірними такі переживання будуть лише для тих, хто їх має. Дійсно, оновлення всього життя для особистості - це певний духовний переворот, який не можна не помітити й не можна вважати недостовірним.

Таким чином, К. Барт під вірою розуміє новий спосіб життя особистості, той справжній спосіб існування, який екзистенціалісти відрізняли від існування звичайного. Своїм завданням К. Барт уважає доведення положення про те, що духовного оновлення не можна досягнути самостійно ані фрілософією, ані містичними вправами, ані будь-яким різновидом духовності. Лише християнство може дати духовне оновлення як досвід надприродного життя після містичної смерті, після самозасудження особистістю самої себе через усвідомлення власної гріховності. Акт самозасудження й акт духовного відновлення відбуваються у відносинах із Богом, і ці відносини, як справжні, якраз і починаються із визнання людиною вироку Бога щодо себе як грішника

Додатковим фрактором надання достовірності вірі $\epsilon$ те, що вона $є$ незбагненною вірністю Бога, явленою в Ісусі. Ця вірність Бога власним обіцянкам може стати властивістю і людини, якщо вона приймає християнську віру. Але при цьому ця віра-вірність ніколи не належить людині як заслуга чи її власна властивість. Це привнесена інтенція і привнесений спосіб життя особистості, які завжди залишаються чудесними. "Істинні мужі Божі знають, що віра сама по собі виправдовуе так само мало, як і все інше людське" [Там само, с. 31] Така теза пов'язана із радикальною загальною позицією: "Не існує ніякого стану чи позиції, способу думок чи настрою, розуміння й пізнання, які самі по собі були б Богоугодні. Те, що в людині та через людину отримує буття, фоорму і протяжність, - це завжди і скрізь $€$ нечестям і непокірністю" [Там само, с. 29]. За таких умов виникнення віри $€$ актом неможливим. К. Барт прямо пише: "Віра, тільки віра - це вимога, яка звернена до всіх, вона - той шлях, яким повинні йти всі - і все-таки не можуть" [Там само, с. 72]. У зв'язку із цим кожна людина повинна визнавати: "можливість віри може бути усвідомлена тільки як неможливість" для людини, і якщо віра все ж таки є, то це - "непояснюване багатство Божої благості", бо "сам я сліпий, але разом із тим - бачу!" [Там само, с. 32]. Безсилля людини розпочати акт віри нагадує безсилля Іова [Там само, с. 21], оскільки не можуть допомогти жодні раціональні чи релігійні аргументи, пояснення, пропозиції, оскільки людина розуміє непояснюваність власної засудженності на гріх і непояснюваність власної виправданості вірою.

Також християнська віра не має якогось об'єкта для власної інтенції, крім Ісуса, а тому вона $є$ вірою в Ісуса, і в ту вірність Бога, що була явлена в ділах Ісуса [Там само, с. 71]. Віра $є$ довірою особистості до вірності Божої, явленої в Ісусі, а отже, і довірою до самого Бога [Там само, с. 70-71]. К. Барт пише: "Християнська віра звершується в зустрічі та спілкуванні віруючого з Тим, у Кого він вірує" [12, с. 97]. Ця зустріч та спілкування не можуть бути охарактеризовані як "релігійний досвід", але лише як "подія". Як подія віра спричинює можливість нового способу існування: "Віра і $€$ та особлива подія, що конституює християнську, а значить, і теологічну екзистенцію" [Там само, с. 98]

Віру практично неможливо визнати, оскільки вона не $€$ стан і властивість [Там само, с. 101], не $є$ вірогідні чи достовірні судження, почерпнуті з Біблії [11, с. 98]. Віра як подія $є$ різким переходом, що очевидний для носія віри, оскільки вона з'являється, як світло, осяває темряву, як прозріння, що дарується сліпому [12, с. 100] Віра характеризується пасивністю людської діяльності. За останньою властивістю бартівська віра аналогічна до православного концепту обожнення. Бог дарує віру, дозволяє їй здійснитися у віруючих [Там само].

Віра обов'язково передбачає прийняття есхатологічної перспективи воскресіння й Царства Божого, щодо якої дійсно не може бути жодних доказів, але яка достовірна лише у світлі прийняття керігми. "Блага звістка - тільки достовірна, у неї можна лише вірити. Віра - це повага до божественного інкогніто, любов до Бога при усвідомленні якісної різниці між Богом і людиною, Богом і світом, прийняття воскресіння як трансформації світу, тобто прийняття божественного "ні" [світові та гріху] у Христі, зачарована зупинка перед Богом" [11, с. 12 13]. Те, що існуватиме Царство Боже і воскресіння мертвих, те, що церква і хрещення особистості $є$ початком вічного Царства Божого і кінцем часу внаслідок Суду Божого, - усе це вимагає значно більшої віри, ніж проста віра в існування Бога, у надання від Бога "релігійного досвіду" і "блаженства".

Підсумовуючи власні роздуми над концептом віри, К. Барт у кінці власної академічної кар'єри давав такий опис віри: "У події віри мова йде про те, що Слово Боже, із властивою йому живою силою Духу, а значить, і з властивою тільки йому владою, звільняє одну людину із багатьох, і тому одна людина з багатьох стає вільною й повинна щоразу ставати вільною для того, щоб така людина схвалила це Слово як абсолютно втішаюче й допомагаюче, але також як зобов'язуюче, а тому безумовно значуще для світу, для церковної громади, для неї самої, щоб вона могла з радісною довірою покластися на те, що в цьому Слові висловлює Сам Бог про Свою любов до світу, до свого народу і до самої цієї людини; щоб вона безумовно покорилася Богові" [12, с. 98-99]. Людина приймає Христа, як світло, що дає надприродні знання й життя, і це і $є$ вірою як у гносеологічно-віросповідному аспекті, так і в аспекті особистої вірності - обидві вони стають можливими через дарунок віри від Бога. Як Христос дарований 
всьому людству і лише Він звершив спасіння, так і віра дарована вірним, які її лише підтверджують, але не створюють. Віра не $\epsilon$ акт, але як подія віра скоріше $€$ подія як те, що із людиною трапилося. Як не-акт і недіяльність віра скоріше $є$ отримана даром причетність до Бога, причому причетність не метафізична, але життєва, екзистенційна.

Сам К. Барт уважає, що дійсне духовне оновлення відбувається лише за умови прийняття всіх біблійних істин як цілого, оскільки Слово Боже, виражене в Біблії, $€$ однією з форм існування Логосу Божого. Але вже Р. Бультман стверджував, що не вся Біблія пов'язана 3 необхідною для спасіння керігмою від Бога, але лише певні фррагменти й смисли, значущі для екзистенції [13]. Тут, дійсно, протестантська теологія потрапляє в певну апорію. 3 одного боку, у дійсності приймається не вся Біблія, як це твердив К. Барт: наприклад, старозавітні норми вважаються необов'язковими, не всі норми поведінки, зафріксовані в Новому Заповіті, виконуються, теологія Бога як Трійці $є$ значно розвинутішою, ніж зафріксовані в Біблії уявлення про Бога. 3 іншого боку, приймається значно більше, ніж мінімум екзистенційно значущих смислів, про які говорив Р. Бультман. Міра прийняття, згідно з К. Бартом і Р. Бультманом, неясна й неочевидна: адже всяке духовне життя при бажанні можна оголосити оновленим, таким, що постало після духовної смерті, таким, що відбувається у Святому Дусі. Стан справ у протестантизмі наочно демонструє, що об'єктивної міри таким способом розуміння Біблії й самоусвідомлення духовного народження не досягається. Сучасний впливовий теолог Н. Т. Райт [14; 15] пропонує вихід із цієї апорії, констатуючи, що фрактично християни приймають біблійний наратив, тобто цілісну розповідь про драму в п'яти діях: творіння, гріхопадіння, створення Ізраїлю, діяльність Ісуса Христа, завершення історії торжеством церкви і царства Божого. Без прийняття цих елементів наративу, а також концептів та цінностей, чеснот і світоглядних парадигм, пов'язаних із різними елементами наративу, неможливе християнство. Для Н. Т. Райта очевидно, що наратив приймається церквою як спільнотою й окремий християнин приймає віру церкви, а отже, носієм норми є саме християнська спільнота, а не екзистенційні переживання особистості. Таким чином, від суб'єктивного критерію віри відбувається перехід до критерію інтерсуб'єктивного. Це відповідає загальній спрямованості розвитку фрілософрії та теології. Бог завжди спілкується зі своїм народом через Писання, і народ також має в Писанні спосіб основного спілкування з Богом [14, с. 13]. Авторитет Писання і його достовірність пов'язані лише з тим, що Біблія представляє Бога. Отже, у біблійних керігми й наративу немає власного авторитету, а йдеться лише про "авторитет Бога, явлений через Писання" [Там само, с. 32]. Гасло Реформації "Тільки Писання" не стверджує, що в Писанні все безпомилково і є абсолютною істиною, але говорить лише про невизнання інших авторитетів - передання, вчительства церкви тощо: "Реформатори ніколи не стверджували, що для спасіння необхідно вірити в кожне слово, що міститься в Писанні. На їхню думку, це гасло, з одного боку, виступало обмежувачем: спасіння не вимагає віри в щось, крім Писання. 3 іншого боку, воно ж слугує застереженням: великі істини Писання - це єдиний шлях до спасіння, i ті, кому довірено служіння проповіді, не мають права привносити у своє навчання щось інше" [Там само, с. 76]. Цілком очікувано, для Н. Т. Райта "великі істини Писання" - це основні концепти, цінності, норми, які безпосередньо наявні в панівному наративі Писання.

Отже, у сучасній протестантській теології від К. Бар- та намітилась тенденція до ототожнення віри з усім надприродним способом існування християнина. Разом із тим, у сучасній протестантській теології існує й альтернативне бачення концепту віри, яке розвиває Дж. Мілбанк [16]. Цей англіканський богослов пропонує повернутися до августинівського розуміння істинного знання як інтуїції, а віру, цілком у дусі Гамана та Якобі, уважати релігійним різновидом такої інтуїції. Ця інтерпретація віри цілком узгоджується із загальним духом системи теології та релігійної фрілософії Дж. Мілбанка як постсекулярної та постмодерної. Дж. Мілбанк не розрізняє знання й віру, фрілософрію та теологію, світське й релігійне: згідно з його інтерпретацією, такі розрізнення були проведені в часи модерну заради вигнання релігії з публічного простору в приватний духовний світ. У часи постмодерну такі розрізнення втрачають власну легітимність, і тому можливі найрізноманітніші твердження про статус віри, статус теології, статус релігії. Сам Дж. Мілбанк пропонує як ідеал єдність віри та розуму, але цілком можливим є й бартівське переконання у вищості віри за розум.

\section{Висновки}

Сучасна протестантська теологія розуміє віру неметафізично. К. Барт під вірою розуміє новий спосіб життя особистості, той справжній спосіб існування, який екзистенціалісти відрізняли від існування звичайного. Цей спосіб життя можливий після прийняття особистістю власного засудження, усвідомленого внаслідок проповіді християнської керігми. Протестантська теологія кінця $\mathrm{XX}$ - початку $\mathrm{XXI}$ століття розуміє віру як вірність спільноти Богові та визнання біблійного наративу (Н. Т. Райт). Альтернативною концепцією $€$ розуміння віри як інтуїтивного знання (Дж. Мілбанк). У цілому, віра протестантськими теологами описується як подія, що відбувається під час спілкування з Богом, і як така віра не є результат діяльності людських здатностей, але чистий дар від Бога, який людина, що його має, може лише прийняти й підтверджувати.

\section{ЛПЕРАТУРА}

1. Кюнг Г. Великие христианские мыслители / Ганс Кюнг ; [пер. с нем. О. Ю. Бойцовой]. - СПб. : Алетейя, 2000. - 442 с.

2. Бальтазар Х. У. фон. Достойна веры лишь любовь / Ханс Урс фон Бальтазар ; [пер. с нем. А. Ярина]. - М. : Истина и Жизнь, 1997. - 124 с.

3. Rowland T. Culture and the Thomist Tradition: After Vatican II / T. Rowland. - Routledge, 2003. - 208 p.

4. Rowland T. Ratzinger's Faith. The theology of pope Benedict XVI / T. Rowland. - Oxford : Oxford University Press, 2008. - 214 p.

5. Kerr F. After Aquinas: versions of Thomism / F. Kerr. Oxford : Blackwell Publishers, 2003. - 254 p.

6. Колодний А. М. Премодерн, модерн, постмодерн в контексті історії християнства / А. М. Колодний // Українське релігієзнавство. - 2005. - № 3 (35)). - С. 5-33.

7. Чорноморець Ю. П. Православна теологія на шляху до нової парадигми / Ю. П. Чорноморець // Філософрська думкаSententiae : Спецвипуск № 3 (2012) "Християнська теологія і сучасна філософія". - Вінниця : ВДТУ, 2013. - С. 74-88.

8. Христокін Г. В. Неопатристика як парадигма сучасної православної теології / Г. В. Христокін // Українське релігієзнавство. - 2007. - № 43. - С. 61-69.

9. Левченко Т. Г. Тлумачення віри як містичної інтуїції в німецькій фрілософії та вплив цієї традиції на російську релігійну думку / Т. Г. Левченко // Філософська думка-Sententiae: Спецвипуск № 2 (2011) "Теологія і філософрія релігії". - Вінниця : ВДТУ, 2011. - С. 119-127.

10. Громадка Й. Л. Перелом в протестантской теологии / Йозеф Лукл Громадка ; [пер. с чеш., англ. Н. Л. Цветкова ; общ. ред. и сост. М. Сато]. - М. : Прогресс, Культура, 1993. 192 c. 
11. Барт К. Послание к римлянам / Карл Барт ; [пер с нем. В. Хулапа]. - М. : ББИ, 2005. - 580 с.

12. Барт К. Введение в евангелическую теологию / К. Барт ; [пер. с нем. Г. Вдовина]. - М. : Центр "Нарния", 2006. - 192 с.

13. Бультман Р. Новый Завет и мифология / Р. Бультман / / Социально-политическое измерение христианства. - М. : Наука, 1994. - С. 302-339.

14. Райт Н. Т. Авторитет Писания и власть Бога / Николас
Томас Райт ; [пер. с англ. О. Розенберг]. - Черкассы : Коллоквиум, 2007. - 152 с.

15. Райт Н. Т. Новый Завет и народ Божий / Николас Томас Райт. - Черкассы : Коллоквиум, 2013. - 704 с.

16. Милбанк Дж. "Постмодерный критический августинизм": краткая сумма в 42 ответах на незаданные вопросы / Дж. Милбанк // Філософська думка-Sententiae: Спецвипуск № 3 (2012) "Християнська теологія і сучасна фрілософрія". Вінниця : ВДТУ, 2013. - С. 108-120.

\section{Левченко Татьяна,} старший преподаватель кафедры политологии и философии

Наиионального университета государственной налоговой службы Украины, г. Ирпень

\section{ИНТЕРПРЕТАЦИИ КОНЦЕПТА ВЕРЫ В СОВРЕМЕННОЙ ПРОТЕСТАНТСКОЙ ТЕОЛОГИИ}

В статье прослежены основные закономерные интерпретации феномена веры в современной протестантской теологии. Автор приходит к выводу, что современная протестантская теология понимает веру неметафизически и персоналистически. Так, К. Барт под верой понимает новый образ жизни личности, тот настоящий способ существования, который экзистенциалисты отличали от существования обычного. Этот образ жизни возможен после принятия личностью собственного осуждения, осознанного вследствие проповеди христианской керигмы (вести). Протестантская теология конца XX - начала XXI века понимает веру как верность сообщества Богу и признание библейского нарратива (Н. Т. Райт). Альтернативной концепцией является понимание веры как интуитивного знания (Дж. Милбанк).

Ключевые слова: современная теология; вера; керигма; нарратив.

Levchenko Tetiana,

Senior Lecturer of the Political Science and Philosophy Department

of the National University of the State Tax Administration of Ukraine, Irpin

\section{INTERPRETATIONS OF THE CONCEPT OF FAITH IN CONTEMPORARY PROTESTANT THEOLOGY}

The paper looks into the main logical interpretations of the phenomenon of faith in contemporary Protestant theology. The research methodology is based on the paradigmal analysis theory of theological knowledge of G. Küng and H. U. von Balthasar, which present-day co-developers are T. Rowland, F. Kerr, A. Kolodnyi, Y. Chernomorets, G. Khrystokin et al. The author draws a conclusion that contemporary Protestant theology interprets faith in a non-metaphysical and personalistic way. Thus, K. Bart perceives faith as a new way of living of an individual, that real mode of existence which existentialists distinguished from usual existence. That way of living becomes possible after an individual accepts his or her own condemnation acknowledged owing to propagation of Christian kerygma. Protestant theology of the late 20th-early 21st centuries interprets faith as commitment to the Community of God and acceptance of the biblical narrative (N. T. Wright). An alternative concept is interpretation of faith as intuitive knowledge (J. Milbank). In general, Protestant theologians describe faith as an occurrence which takes place during communication with God and as such, faith is not a result of activities of human abilities but a genuine gift from God, which the possessor can only accept and affirm.

Key words: contemporary theology; faith; kerygma; narrative.

\section{REFERENCES}

1. Küng Hans (2000), Great Christian Thinkers (translated), Aleteyya, St. Petreburge, 442 p. (rus).

2. Balthasar Hans Urs von (1997), Only love is worthy of faith (translated), Istyna i Zhyzn, Moscow, 124 p. (rus)

3. Rowland T. (2003), Culture and the Thomist Tradition: After Vatican II. Routledge, 208 p. (engl).

4. Rowland T. (2008), Ratzinger's Faith. The theology of pope Benedict XVI. Oxford University Press, Oxford, 214 p. (engl).

5. Kerr F. (2003), After Aquinas: versions of Thomism, Blackwell Publishers, Oxford, 254 p. (engl).

6. Kolodnyi A. M. (2005), Christianity is the postmodern era, Ukrainske relihiyeznavstvo, № 3 (35), pp. 5-33 (ukr).

7. Chornomorets Yu. P. (2013), Filosofska dumka-Sententiae: Special Issue, № 3, VDTU, Vinnytsia, pp. 74-88 (ukr). (ukr).

8. Khrystokin H. V. (2007), New patristic a paradigm of modern Orthodox theology in: Ukrainske relihiyeznavstvo, № 43, pp. 61-69

9. Levchenko T.H. (2011), Filosofska dumka-Sententiae: Special Issue, № 2, VDTU, Vinnytsia, pp. 119-127 (ukr).

10. Hromádka Josef Lukl (1993), Turning point in Protestant theology (translated), Prohress, Kultura, Moscow, 192 p. (rus).

11. Barth Karl (2005), The Epistle to the Romans (translated), BBY, Moscow 580 p. (rus).

12. Barth Karl (2006), Evangelical Theology: An Introduction (translated), Tsentr «Narnyya», Moscow, 192 p. (rus).

13. Bultman R. (1994), Sotsyalno-politicheskoye izmerenye khristianstva, available at: http://www.gumer.info/bogoslov_Buks/ bibliologia/Article/bultm.php (rus).

14. Wright N. T. (2007), The authority of Scripture in the power of God (translated) Kollokvium, Cherkassy, 152 p. (rus).

15. Wright N. T. (2013), The New Testament and the People of God Kollokvium, Cherkassy, 704 p. (rus).

16. Mylbank Dzh. (2013), Filosofska dumka-Sententiae: Special Issue, № 3, VDTU, Vinnytsia, pp. 108-120 (ukr).

() Левченко Тетяна

Надійшла до редакції 18.05.2015 